\title{
Effect of dietary protein programs on pullet development and egg production performance of local hens
}

\author{
A. S. Hussein \\ Department of Arid Land Agriculture, College of Food Systems, UAE University \\ P.O. Box 17555, Al-Ain, United Arab Emirates, E-mail: hhussein@uaeu.ac.ae
}

\begin{abstract}
The objective of this study was to investigate the effect of dietary protein levels on pullet development and egg production performance of local hens. One hundred sixty local chicken pullets were used in this study. During the rearing period, the pullets were divided randomly at a density of 16 chicks per cage in rearing pens. During week 1 , all birds were fed a starter diet containing 19\% crude protein (CP). The experimental treatments consisted of two protein sequence regimens. The semi-constant protein sequence consisted of feeding the birds a $16 \%$ protein diet during weeks 2 to 14 , and a $13 \%$ protein diet during weeks $15-20$. The second regimen was a decreasing protein sequence (conventional method) consisting of feeding 19,16, and 13\% crude protein diets during weeks 2 through 6,7 through 14, and 15 through 20, respectively. During the laying period, weeks 21 through 40, half of the groups in each of the protein sequence treatments were fed 19\% CP and the other half $17.5 \% \mathrm{CP}$ diets. Body weight and feed intake of the local pullets were similar in both protein sequence treatments at weeks six, fourteen, and twenty during the rearing period. During the laying period, egg production of hens fed the decreasing protein sequence during the rearing period was numerically higher than the semiconstant protein sequence at weeks 21 through 40, but not significantly different. Body weight and feed intake were not significantly affected by the dietary protein sequence. In addition, egg weight during weeks 21-24 and 29-40 was not affected by rearing diets, but hens fed the decreasing protein sequence diet had significantly $(\mathrm{P}<.05)$ higher egg weight than the other rearing protein diet during weeks $25-28$. The main effect of the dietary protein level in the layer diet on egg weight was significantly higher in hens fed the higher protein layer diet (19\% CP) than the lower protein layer diet during weeks $21-24$ and $33-40$ of the laying period. The data showed that raising layer dietary levels to $19 \%$ during the laying period also increased average egg size.
\end{abstract}

Key words: Pullet, rearing, protein sequence, egg production

تأثير برلمجهستوبلت البروتين النذائي عل نمو البلرى و ألاء الباج البيلن المهلي ألمسسليملن تسبن

قعم زراعة الأرالف الفاطة ،كليةطام الأغنة ،جلمة الإمارل المربية المتصة.صب:17555 المن - الإمارل المربية المخدة

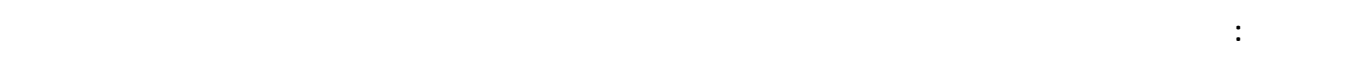

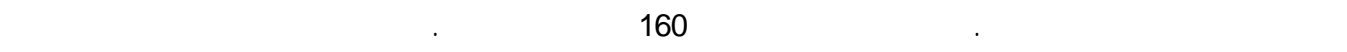

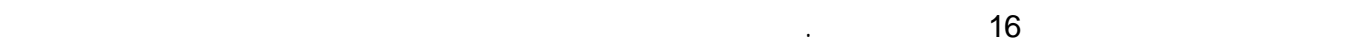

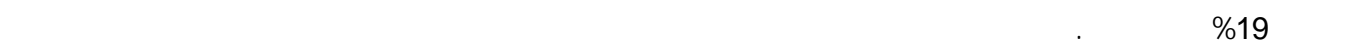

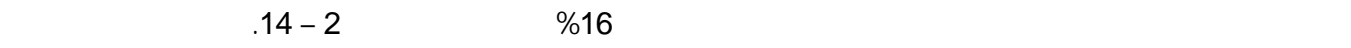

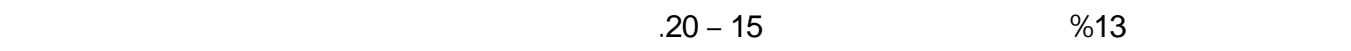

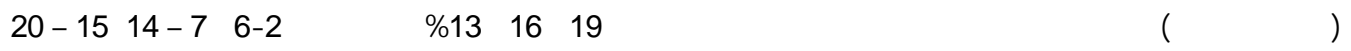

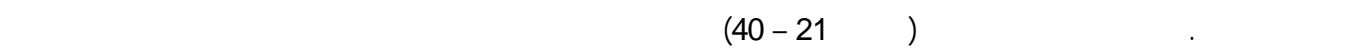

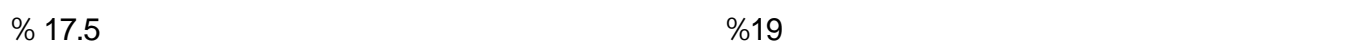

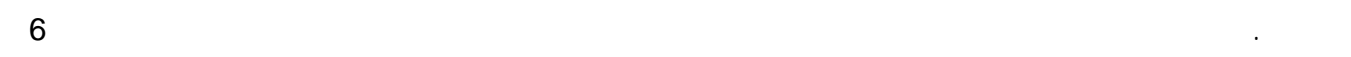

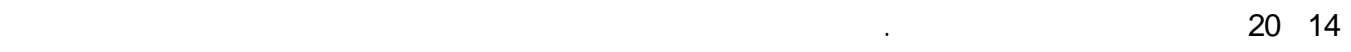

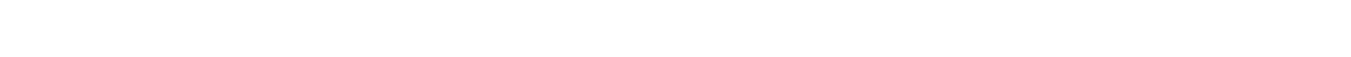

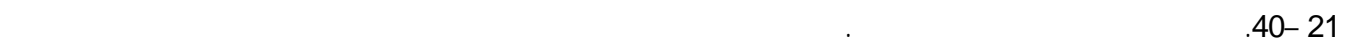

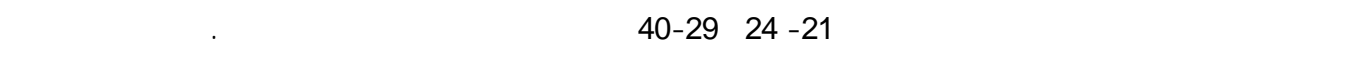

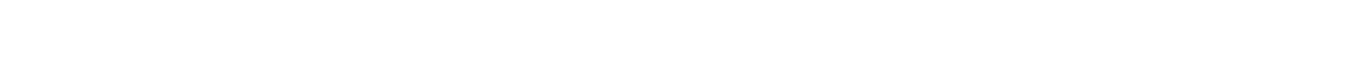

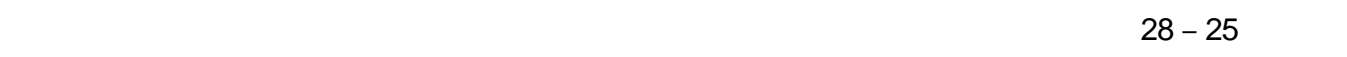

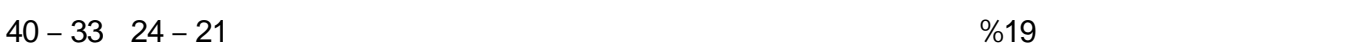

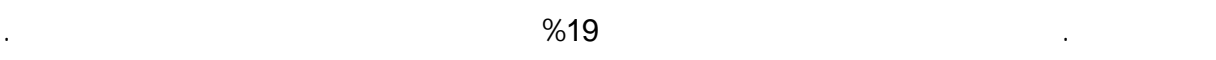
كلماتمفناحية: البدارى، نمو، مستويت البروتين، إلتاج البيض 


\section{A. S. Hussein}

\section{Introduction}

The poultry industry in the United Arab Emirates (UAE) has been growing exponentially to meet the higher demand for eggs and broilers. However, the industry imports all growing and producing chickens selected for their excellent performance in producing broiler meat or eggs for human consumption. Yet, the local population largely prefers to eat eggs produced from local hens. However, local pullets have low growth performance and layers have low egg production performance (46\%). Also, the laying hens take longer (about 24 weeks) to come to production (AS Hussein, unpublished data; unreferenced) than commercial pullet strains (about 18 weeks) Hussein et al. (1996). In addition the author is not aware of any research conducted regarding improving the growth performance of local pullets and/or increasing egg production of local laying hens under UAE climatic conditions. Also, it is known that birds perform better when fed a balanced protein and amino acid diet under a good lighting program.

For the last three decades there have been different techniques used to feed replacement pullets in the egg industry, for several reasons. One of the concerns is producing heavy birds for laying eggs. Another concern is delaying sexual maturity of hens to match the desired optimum body weight in order to increase egg size and the egg production season (North and Bell, 1990). Summers and Lesson (1978) reported that when hens were given the opportunity to select their diets, they consumed rations that contained increasing levels of protein, as the pullets became older. In a different study, Lesson and Summers (1979), compared the growth development and subsequent laying performance of pullets fed a conventional rearing diet with a step-up protein series in which protein levels were reversed, compared to the conventional step-down protein diet. The step-up treatment resulted in lower body weights at 20 weeks of age and lower intake of protein and energy during the 20 weeks growth period. During the laying period it resulted in equivalent egg production, smaller eggs, and greater shell deformation.

It is known that the dietary protein requirements for pullet development published by the NRC (1994) are as follows: $18 \%$ for 0 to 6 weeks, $16 \%$ for 6 to 12 weeks, and $15 \%$ for 12 to 18 weeks of age. Cantor and Johnson (1985) reported the results of a study that compared the effect of feeding diets with decreasing, increasing and constant levels of dietary protein to replacement pullets up to 20 weeks of age. They found that the increasing protein technique lowered body weight of hens from weeks 3 to 20 , and decreased egg production during the first five weeks after lighting, yet feeding a constant $16 \%$ protein diet did not affect body weight or egg production. Hussein et al., 1996 evaluated the effect of using protein sequence, namely diets with increasing, decreasing and constant levels during weeks 2 through 18, in combination with the use of high or low energy levels, upon pullet development and subsequent egg production performance. They reported that increasing dietary protein levels during weeks 2 to 6 significantly increased body weight and feed intake of replacement pullets up to 14 weeks of age. Also, the use of a high-energy diet improved weight gain and decreased feed intake during weeks 15 through 18 . Mortality and days-to- $50 \%$ egg production, as well as egg production, feed intake, feed conversion, and egg weights were not affected by dietary treatments. They also reported that raising crude protein in the layer diet from 16 to $19 \%$ significantly increased egg weight.

The objectives of this study were: 1) to determine the effect of dietary protein/amino acid levels on the growth development of local pullets; 2) to determine the effect of dietary 
protein/amino acid levels of layer diets on egg production performance of local hens; 3 ) to determine the effect of level of protein/amino acids for developing local pullets on egg size and egg production of local laying hens in the UAE.

\section{Materials and methods}

\section{Rearing Period}

A total of 160 local black chicks, 1 day of age, were housed in Petersime battery brooders at a density of 16 birds per cage during weeks 1 through 6 . Starting week 7 through 20, birds were transferred to floor pens at the same density. All birds were fed a starter diet containing 19\% CP for the first week. After that, 5 replicate groups of 16 birds were randomly assigned to each of the two dietary treatments. The experimental design consisted of using two protein sequences (Table 1). The semi-constant protein sequence consisted of feeding pullets $16 \%$ protein during weeks 2 through 14, and $13 \%$ protein during weeks 15 through 20 . The decreasing protein sequence (conventional method) consisted of feeding 19,16 , and $13 \%$ protein during weeks 2 through 6, 7 through 14 , and 15 through 20 , respectively.

Rearing dietary protein sequence diets 19, 16 and $13 \% \mathrm{CP}$ were previously reported and outlined by Hussein (2000). The 19\% CP diet contained $19 \%$ protein, $3.0 \mathrm{Mcal} \mathrm{ME} / \mathrm{kg}$, 0.34\% Met, $0.67 \%$ Met+Cys, $0.99 \%$ Lys, $1.0 \%$ calcium and $0.5 \%$ available phosphorus. The $16 \% \mathrm{CP}$ diet contained $16 \%$ protein, $3.0 \mathrm{Mcal} \mathrm{ME} / \mathrm{kg}, 0.29 \% \mathrm{Met}$, $0.57 \%$ Met+Cys, $0.77 \%$ Lys, $1.0 \%$ calcium and $0.5 \%$ available phosphorus. The $13 \%$ CP diet contained $13.5 \%$ protein, $3.0 \mathrm{Mcal}$ $\mathrm{ME} / \mathrm{kg}, 0.25 \%$ Met, $0.49 \%$ Met + Cys, $0.59 \%$ Lys, $1.0 \%$ calcium and $0.5 \%$ available phosphorus

Table 1. Dietary protein feeding programs of replacement pullets during the rearing period ${ }^{1}$

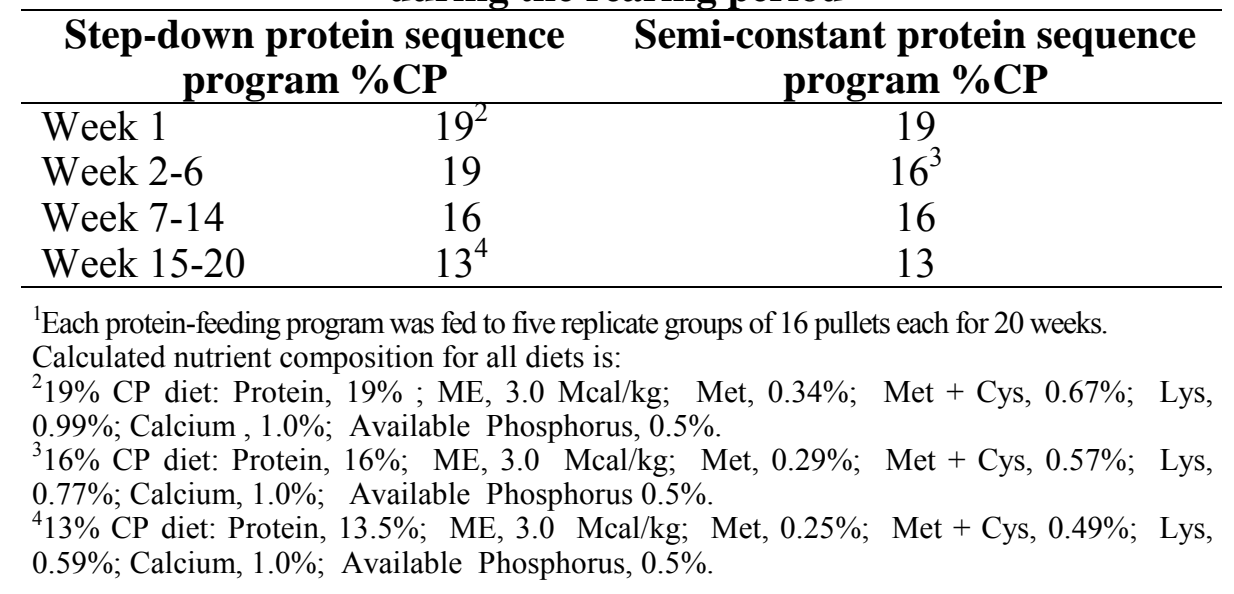

\section{Laying Period}

At the beginning of 21 weeks of age, 10 representative pullets were selected randomly from each group for the laying period; thus the number of replicates within each protein sequence treatment became 6 replicates of ten birds/each. During this period, hens were photostimulated by increasing the light from 8 to 13 hours of light/day and gradually increased $1 / 2$ hour weekly until reaching 17 hours of light/day. Hens were fed corn-soybean meal layer diets containing $3.52 \% \quad \mathrm{Ca}$ and $0.40 \%$ available phosphorus. During this laying period half of the groups (three replicates) in each of the two protein treatments were given $19 \% \mathrm{CP}$ and the other half were given a $17.5 \% \mathrm{CP}$ experimental layer diets for twenty 


\section{A. S. Hussein}

weeks. The first diet contained 19\% protein, 2.83 Mcal ME $/ \mathrm{kg}, 0.4 \%$ Met, $0.72 \%$ Met+Cys, $1.02 \%$ Lys, $3.6 \%$ calcium and $0.44 \%$ available phosphorus. The second layer diet contained 17.5\% protein, 2.83 Mcal ME $/ \mathrm{kg}, 0.38 \%$ Met, $0.67 \%$ Met+Cys, $0.83 \%$ Lys, $3.52 \% \mathrm{Ca}$, $0.40 \%$ Available P. (Table 2).

The nutrient composition of the experimental diets was calculated based on information reported and found in the ingredient tables of Scott et al. 1982. Feed and water was provided ad libitum during the rearing period, data regarding feed intake and weight of pullets was obtained at 6,14 and 20 weeks of age. During the laying period, feed intake and body weight were measured periodically. Egg production data was collected daily and calculated periodically (every 28 days). During the last three consecutive days of each collection period, eggs were kept for measuring Haugh unit scores, eggshell thickness and eggshell weights. Eggshell thickness was measured using Ames pocket thickness instrument (Series 25M5, B.C. Ames Co., Waltham, MA). Haugh unit scores were determined using Ames micrometer adjusted to egg weight (Model S-8400, B.C. Ames Co., Waltham, MA), according to methods used and outlined by Bish et al. (1984) and Austic and Nesheim (1990). The collected data from the three-day egg collection were pooled within each replicate Statistical Analysis. The collected data from the rearing period were tested for significance using the ttest for two samples using a statistical analysis program for microcomputers (Statistics, V. 4.0, Analytical Software, Tallahassee, FL.). The collected data from the laying period were subjected to an ANOVA based on a factorial design of treatments in a completely randomized design using the General Linear Models (GLM) producers. The test of least significant difference was applied to separate means. A probability level of $\mathrm{P}<0.05$ was required for significance (Snedecor and Cochran, 1980)j

Table 2. Composition of experimental layer diets

\begin{tabular}{|c|c|c|}
\hline Ingredient & 19\% CP Diet & 17\% CP Diet \\
\hline Yellow corn & 57.110 & 67.115 \\
\hline Meat Meal & -- & 5.615 \\
\hline Soybean meal (48\% CP) & 29.400 & 17.800 \\
\hline Corn Oil & 2.000 & -- \\
\hline Salt & 0.400 & 0.340 \\
\hline Limestone $(38 \% \mathrm{Ca})$ & 8.300 & 7.700 \\
\hline Dicalcium phosphate & 1.700 & 0.330 \\
\hline Vitamin-mineral mix ${ }^{1}$ & 1.000 & 1.000 \\
\hline DL-methionine & 0.090 & 0.100 \\
\hline \multicolumn{3}{|c|}{ Calculated Nutrient Composition } \\
\hline ME, Mcal/kg & 2.83 & 2.83 \\
\hline Protein, \% & 19.10 & 17.50 \\
\hline Lysine, \% & 1.02 & 0.83 \\
\hline Methionine, \% & 0.40 & 0.38 \\
\hline Methionine+cystine, \% & 0.72 & 0.67 \\
\hline Calcium, \% & 3.60 & 3.52 \\
\hline Phosphorus, available, $\%$ & 0.44 & 0.40 \\
\hline
\end{tabular}




\section{Results}

The effect of dietary protein levels on body weight and feed intake of replacement pullets is shown in Table 3. Neither dietary protein sequence programs affected body weight or feed intake of pullets. Also, the main effect of the dietary protein level series used for local pullet rearing on laying hen performance during weeks 21 through 40 is shown in Table 4. Hen-day egg production slightly increased by using the decreasing protein sequence $(19-16-13 \% \quad \mathrm{CP})$ program compared to the other protein program. Feed intake measured at weeks 21-24 and 33-40 was not significantly affected by the two protein programs, but feed intake of hens fed the step-down protein sequence program during weeks 25-32 was significantly $(\mathrm{P}<0.05)$ higher than that of those birds fed the other protein treatment. Body weight was not affected by the dietary protein treatments. Also, egg weight was not significantly affected by dietary protein treatments, except during weeks 25-28, where eggs collected from the step-down protein program were significantly heavier than eggs of the semiconstant protein program. Furthermore, dietary protein programs did not significantly affect Haugh unit scores, eggshell thickness or eggshell weight, as shown in Table 5.

Table 3. Effect of dietary protein levels on body weight (at weeks 6, 14, and 20) and feed intake (g/bird/day) of local replacement pullets ${ }^{1}$

\begin{tabular}{|c|c|c|c|}
\hline Weeks of age & $\begin{array}{c}\text { Dietary } \\
\text { protein } \\
\text { sequence }\end{array}$ & $\begin{array}{c}\text { Body } \\
\text { weight, } g\end{array}$ & $\begin{array}{c}\text { Feed } \\
\text { intake, } g\end{array}$ \\
\hline \multirow[t]{2}{*}{$2-6$} & 19 & 337.7 & 36.6 \\
\hline & 16 & 341.9 & 36.7 \\
\hline Pooled SEM & & 8.0 & 0.6 \\
\hline \multirow[t]{2}{*}{$7-14$} & $19-16$ & 1053 & 56.2 \\
\hline & $16-16$ & 1007 & 56.0 \\
\hline Pooled SEM & & 23.0 & 0.7 \\
\hline \multirow[t]{2}{*}{$15-20$} & $19-16-13$ & 1328 & 69.9 \\
\hline & $16-16-13$ & 1423 & 70.7 \\
\hline Pooled SEM & & 37.0 & 2.5 \\
\hline
\end{tabular}


Table 4. Main effect of dietary protein level series used for pullet rearing on laying hen performance during Weeks 21 through 40

\begin{tabular}{|c|c|c|c|}
\hline Variable & $\begin{array}{c}19-16-13 \\
\text { Sequence } \\
\end{array}$ & $\begin{array}{c}16-16-13 \\
\text { Sequence } \\
\end{array}$ & $\begin{array}{c}\text { Pooled } \\
\text { SEM }\end{array}$ \\
\hline \multicolumn{4}{|c|}{ Hen-day production, $\%$} \\
\hline Weeks 21-24 & 54.8 & 49.7 & 7.4 \\
\hline Weeks 25-28 & 79.0 & 68.8 & 5.1 \\
\hline Weeks 29-32 & 77.6 & 73.5 & 4.3 \\
\hline Weeks 33-36 & 75.5 & 73.4 & 7.3 \\
\hline Weeks 37-40 & 72.3 & 71.9 & 4.4 \\
\hline Average & 71.8 & 67.5 & 2.9 \\
\hline \multicolumn{4}{|c|}{ Feed intake, g/hen/d } \\
\hline Weeks 21-24 & 102.9 & 94.1 & 4.5 \\
\hline Weeks 25-32 & $121.9^{\mathrm{a}}$ & $110.1^{\mathrm{b}}$ & 3.3 \\
\hline Weeks 33-40 & 130.7 & 120.7 & 10.3 \\
\hline Average & 116.1 & 109.2 & 3.3 \\
\hline \multicolumn{4}{|c|}{ Body Weight, g } \\
\hline $24^{\text {th }} \mathrm{wk}$ & 1494 & 1440 & 50.0 \\
\hline $32^{\text {nd }} \mathrm{wk}$ & 1579 & 1535 & 47.7 \\
\hline $40^{\text {th }} \mathrm{wk}$ & 1648 & 1605 & 66.8 \\
\hline \multicolumn{4}{|l|}{ Egg weight, g } \\
\hline Weeks 21-24 & 37.8 & 37.3 & 1.1 \\
\hline Weeks 25-28 & $44.5^{\mathrm{a}}$ & $42.6^{\mathrm{b}}$ & 0.7 \\
\hline Weeks 29-32 & 44.9 & 44.8 & 0.9 \\
\hline Weeks 33-36 & 46.3 & 46.1 & 0.6 \\
\hline Weeks 37-40 & 47.9 & 47.2 & 0.7 \\
\hline Average & 44.4 & 43.6 & 0.6 \\
\hline
\end{tabular}


Table 5. Main effect of dietary protein level series for pullet rearing on local laying hen performance during Weeks 21 through 40

\begin{tabular}{lccc}
\hline Variable & $\mathbf{1 9 - 1 6 - 1 3}$ & $\mathbf{1 6 - 1 6 - 1 3}$ & $\begin{array}{c}\text { Pooled } \\
\text { SEM }\end{array}$ \\
\hline Haugh unit scores & & & \\
Weeks 21-24 & 73.7 & 75.8 & 2.4 \\
Weeks 25-28 & 78.7 & 78.7 & 1.4 \\
Weeks 29-32 & 72.7 & 73.5 & 1.5 \\
Weeks 33-36 & 80.5 & 81.0 & 0.7 \\
Weeks 37-40 & 76.0 & 75.3 & 1.0 \\
Eggshell thickness, mm & & & \\
Weeks 21-24 & 0.400 & 0.388 & 0.005 \\
Weeks 25-28 & 0.397 & 0.397 & 0.007 \\
Weeks 29-32 & 0.411 & 0.415 & 0.004 \\
Weeks 33-36 & 0.393 & 0.388 & 0.005 \\
Weeks 37-40 & 0.397 & 0.382 & 0.007 \\
Eggshell weight, g & & 5.1 & \\
Weeks 21-24 & 5.7 & 5.5 & 0.3 \\
Weeks 25-28 & 5.3 & 5.6 & 0.3 \\
Weeks 29-32 & 5.1 & 0.2 \\
Weeks 33-36 & & 5.9 & 0.1 \\
Weeks 37-40 & 5.1 & \\
\hline
\end{tabular}

The main effects of dietary protein levels in the layer diet on local hen egg performance during weeks 21 through 40 are shown in Table 6. Hen-day egg production increased when protein levels in the layer diets increased from $17.5 \%$ to 19\%. However, this improvement was not statistically significant. Furthermore, raising layer dietary protein significantly increased egg weight during weeks 21-24,
33-36 and 37-40, but not during weeks $25-$ 32. In addition, protein levels in the layer diets did not significantly affect body weight or feed intake during weeks 21-24 and 33-40, nor did they affect eggshell weight, eggshell thickness, or Haugh unit scores, except during weeks 33-36 for Haugh unit scores only (Table 7). 
Table 6. Main effect of dietary protein level of layer diets on local laying hen performance during Weeks 21 through 40

\begin{tabular}{lccc}
\hline Variable & $\mathbf{1 9 \%}$ CP & $\mathbf{1 7 . 5 \%}$ CP & Pooled SEM \\
\hline Hen-day production, \% & & & \\
Weeks 21-24 & 58.7 & 45.7 & 7.4 \\
Weeks 25-28 & 77.8 & 69.9 & 5.1 \\
Weeks 29-32 & 70.9 & 80.2 & 4.3 \\
Weeks 33-36 & 71.0 & 77.9 & 7.3 \\
Weeks 37-40 & 68.5 & 75.7 & 4.4 \\
Average & $\mathbf{6 9 . 4}$ & $\mathbf{6 9 . 9}$ & $\mathbf{2 . 9}$ \\
Feed intake, g/hen/d & & & \\
Weeks 21-24 & 101.8 & 95.1 & 4.5 \\
Weeks 25-32 & $122.1^{\mathrm{a}}$ & $109.9^{\mathrm{b}}$ & 3.3 \\
Weeks 33-40 & 126.0 & 125.4 & 10.3 \\
Average & $\mathbf{1 1 7 . 8}^{\mathrm{a}}$ & $\mathbf{1 0 7 . 4 ^ { \mathrm { b } }}$ & $\mathbf{3 . 3}$ \\
Body Weight, g & & & \\
24 $4^{\text {th }}$ wk & 1527 & 1408 & 50.2 \\
32 & 1596 & 1518 & 47.4 \\
40 $0^{\text {th }}$ wk & 1637 & 1616 & 66.8 \\
Egg weight, g & & & \\
Weeks 21-24 & $39.1^{\mathrm{a}}$ & $36.0^{\mathrm{b}}$ & 1.1 \\
Weeks 25-28 & 44.0 & 43.1 & 0.7 \\
Weeks 29-32 & 45.8 & 44.0 & 0.9 \\
Weeks 33-36 & $47.1^{\mathrm{a}}$ & $45.4^{\mathrm{b}}$ & 0.6 \\
Weeks 37-40 & $48.4^{\mathrm{a}}$ & $46.7^{\mathrm{b}}$ & 0.7 \\
Average & $\mathbf{4 5 . 1}^{\mathrm{a}}$ & $\mathbf{4 3 . 0}^{\mathbf{b}}$ & $\mathbf{0 . 6}$ \\
\hline a,b & &
\end{tabular}

Table 7. Main effect of dietary protein level of layer diets on local laying hen performance during Weeks 21 through 40

\begin{tabular}{lccc}
\hline Variable & $\mathbf{1 9} \% \mathbf{C P}$ & $\mathbf{1 7 . 5} \% \mathbf{C P}$ & Pooled SEM \\
\hline Haugh unit scores & & & \\
Weeks 21-24 & 73.0 & 76.5 & 2.4 \\
Weeks 25-28 & 78.0 & 79.3 & 1.4 \\
Weeks 29-32 & 71.8 & 74.3 & 1.5 \\
Weeks 33-36 & $78.3^{\mathrm{b}}$ & $83.2^{\mathrm{a}}$ & 0.7 \\
Weeks 37-40 & 74.8 & 76.5 & 1.0 \\
Eggshell thickness, mm & & & \\
Weeks 21-24 & 0.397 & 0.392 & 0.005 \\
Weeks 25-28 & 0.393 & 0.400 & 0.007 \\
Weeks 29-32 & 0.410 & 0.417 & 0.004 \\
Weeks 33-36 & 0.390 & 0.392 & 0.005 \\
Weeks 37-40 & 0.387 & 0.392 & 0.007 \\
Eggshell weight, g & & & \\
Weeks 21-24 & 5.3 & 5.9 & 0.3 \\
Weeks 25-28 & 5.6 & 5.4 & 0.3 \\
Weeks 29-32 & 5.1 & 5.3 & 0.2 \\
Weeks 33-36 & 5.9 & 5.9 & 0.1 \\
Weeks 37-40 & 6.0 & 6.0 & 0.2 \\
a,b Means within a row with no common superscript differ significantly $(\mathrm{P}<0.05)$.
\end{tabular}




\section{Discussion}

\section{Pullets Growth Performance}

Previously, Hussein et al. (1996) found a considerable variation in the levels of dietary protein used by various commercial breeders to develop replacement pullets. In addition, these levels can vary depending upon the different genetic strains used. Since the genetic potential of the local laying hens used in this present study had not been previously tested nor identified, it was of interest to apply new technology used with commercial egg-type strains to establish the protein requirement of local pullets in order to achieve maximum egg production performance.

Hussein (2000) used similar protein sequence treatments; step-down protein $(19-16-13 \% \quad \mathrm{CP})$ and semi-constant protein (16-16-13\% CP) programs in developing a commercial pullet strain (Lohmann) under the hot climatic conditions of the UAE. He found that dietary protein levels did not affect body weight and feed intake of replacement pullets during the rearing period. These results agreed with those obtained in the present study, as shown in Table 3. In addition, Doran et al. (1983) reported that using the step-down protein (19-16-13\% $\mathrm{CP})$ system in developing pullets significantly increased body weight at 20week of age compared to the step-up protein (13-16-19 \% CP) system. Also, they found that energy levels used in the step-down protein system had no significant effect on pullet body weight at 20 -week of age. In this present study it was found that neither protein systems (step-down vs. semi-constant) had an effect on body weight (Table 3). On the other hand, McNaughton et al. (1977) investigated the effect of dietary protein and energy levels on pullet body weight of birds reared in hot-cyclic temperature. They reported that pullet body weight at week 20 was not affected by either dietary protein or energy.
Hussein (2000) found that feed intake of replacement pullets was similar when birds were fed either step-down or semiconstant protein systems during the rearing period (except during weeks 2-6) under hot-cyclic temperature. These results were similar to those obtained in the present study, in which similar experimental conditions were used, but with different types of birds (local hens). Also, Cantor and Johnson (1985) and Hussein et al. (1996), found that pullets reared on the step-down protein regimen significantly increased feed intake compared to birds fed the constant protein (16-16-16 \% CP) regimen, but only during weeks 2-6; feed intake was the same for both regimens in weeks 714 and 15-18 during the rearing period.

\section{Egg Production Performance}

The main effect of dietary protein level series used for local pullet rearing on laying hen performance during weeks 21 through 40 is shown in Table 4. Hen-day egg production was slightly higher in hens fed the step-down protein system compared to hens fed the other protein regimen. However, these differences were not statistically significant. On the other hand, the average egg production obtained under these experimental conditions in both protein systems was much better than previously found. Also, a significant increase in egg weight was found in hens fed the step-down protein regimen compared to hens fed the semi-constant protein system at 28 weeks of age (Table 4).

Body weight during the laying period was not significantly affected by the dietary protein treatments (Table 4); neither was feed intake except during week 32 . These results agreed with those obtained by Hussein et al. (1996), and were similar to those of Hussein (2000). The effect of dietary protein level of layer diets on local laying hen performance during weeks 21 through 40 is shown in Table 6. Feeding local hens a layer diet 
containing $19 \%$ or $17.5 \% \quad \mathrm{CP}$ increased egg production during the laying period compared to preliminary trial egg production data. Body weight and feed intake (except feed intake at 32 weeks of age) were not significantly affected by laying hen diets. On the other hand, egg weight was significantly increased in local hens fed $19 \%$ CP compared to those hens fed the $17.5 \% \mathrm{CP}$ layer diet at 24, 36 and 40 weeks of age. These results agreed with the findings of Keshavarz, 1984; Hussein et al., 1996; and Hussein, 2000.

The main effect of dietary protein series for pullet rearing on local laying hen performance during weeks 21 through 40 is shown in Table 5. Pullet rearing protein diets did not significantly affect Haugh unit scores, eggshell thickness, and eggshell weight, and this agrees with the findings of Stockland and Blaylock (1974). A similar trend was observed regarding the effect of protein levels of the layer diets on the above parameters performance as shown in Table 7 . Hussein (2000) used similar experimental protein treatments with a commercial eggtype strain (Lohmann). He found that rearing protein level diets had no significant effect on Haugh unit scores, egg weight and eggshell weight (weeks 19-22 and 31-38) during the laying period. These results agreed with those found in the present study.

In conclusion, neither dietary protein levels affected body weight or feed intake of local replacement pullets (Table 3). Hen-day egg production increased using the decreasing protein sequence program during the rearing period, and when protein levels in the layer diets were increased from 17.5 to $19 \%$. However, these improvements were not statistically significant (Tables 4 \& 6). Raising layer dietary protein levels from 17.5 to $19 \%$ during most of the laying period (Table 6) significantly increased egg weight. The data of this study showed that either protein sequence program could improve pullet development and egg production performance of local hens. Also, more research is needed in this area to fully understand and improve egg production performance of local hens.

\section{References}

Austic, R. E., and M. C. Nesheim, 1990. Poultry Production. $13^{\text {th }}$ ed. Lea \& Febiger, Malvern, PA.

Bish, Connie L., W. L. Beane, P. L. Ruszler, and J. A. Cherry, 1984. Modified step-up protein feeding regimens for egg-type chickens. 1. Growth and production performance. Poultry Sci. 63:2450-2457.

Cantor, A. H., and T. H. Johnson, 1985. Influence of dietary protein sequence and selenium upon development of pullets. Poultry Sci. 64:(Suppl. 1):75. (Abstr.)

Hussein, A. S., 2000. The use of stepdown, and modified constant protein feeding systems in developing pullets reared in hot climates. Anim Feed Sci. \& Technol. 85: 171-181.

Hussein, A. S., A. H. Cantor, A. J. Pescatore and T. H. Johnson, 1996. Effect of dietary protein and energy levels on pullet development. Poultry Sci. 75:973-978.

Leeson, S., and J. D. Summers, 1979. Step-up protein diets for growing pullets. Poultry Sci. 58:681-686.

Doran, B. H., W. F. Krueger, and J. W. Bradley, 1983. Effect of stepdown and step-up protein-energy feeding systems on egg-type pullet growth and laying performance. Poultry Sci. 62:255-262.

Keshavarz, K., 1984. The effect of different dietary protein levels in the rearing and laying periods on 
performance of White Leghorn chickens. Poultry Sci. 63:2229-2240.

McNaughton, J. L., L. F. Kubena, J. W. Deaton, and N. F. Reece, 1977. Influence of dietary protein and energy on the performance of commercial egg-type-pullets reared under summer conditions. Poultry Sci. 56:1391-1398.

NRC. 1994. National Research Council. Nutrient Requirements of Poultry. 9th rev. ed. National Academy Press. Washington, DC.

North, M.O., and D. D. Bell, 1990. Commercial Chicken Production Manual. $4^{\text {th }}$ Ed. Chapman \& Hall, New York.
Summers, J. D., and S. Leeson, 1978. Dietary selection of protein and energy by pullets and broilers. Brit. Poultry Sci. 19:425-430.

Scott, M. L., M. C. Neshiem, and R. J. Young, 1982. Nutrition of the Chicken. 3rd ed. M. L. Scott and Associates, Ithaca, NY.

Snedecor, G. W., and W. G. Cochran, 1980. Statistical Methods. 7th ed. Iowa State University Press, Ames, IA.

Stockland, W. L., and T.G. Blaylock, 1974. The influence of temperature on the protein requirements of cage reared replacement pullets. Poultry Sci. 53:1174-1187 